\title{
An Investigation of the Effect of Moral Maturity on Consumer Ethics
}

\author{
Sinem SARGIN iD a Leyla LEBLEBİCi KOÇER (iD $b$ \\ aNuh Naci Yazgan Üniversitesi, İktisadi ve İdari Bilimler Fakültesi, İşletme Bölümü, Kayseri, Türkiye. ssargin@nny.edu.tr \\ `Erciyes Üniversitesi, İktisadi ve İdari Bilimler Fakültesi, İşletme Bölümü, Kayseri, Türkiye. leyla@erciyes.edu.tr,
}

\begin{tabular}{|c|c|}
\hline ARTICLE INFO & ABSTRACT \\
\hline $\begin{array}{l}\text { Keywords: } \\
\text { Moral maturit }\end{array}$ & $\begin{array}{l}\text { Purpose - The purpose of this research is to examine the impact of consumers' levels of moral maturity } \\
\text { on their unethical behavior. }\end{array}$ \\
\hline $\begin{array}{l}\text { Ethics } \\
\text { Consumer Ethics }\end{array}$ & $\begin{array}{l}\text { Design/methodology/approach - The research model of this study examines the effect of moral } \\
\text { maturity on consumer ethics dimensions ("actively benefiting from an illegal situation" and } \\
\text { "benefiting from actions perceived as harmless"). The universe of this descriptive research consists of }\end{array}$ \\
\hline Structural Equation Model & $\begin{array}{l}\text { consumers living in Turkey. The online survey method was applied to } 457 \text { consumers selected by } \\
\text { convenience sampling method. While creating the questionnaire, moral maturity statements were }\end{array}$ \\
\hline Received 1 May 2021 & prepared by using the scales developed by Şengün and Kaya (2007), and the consumer ethics \\
\hline Revised 20 June 2021 & statements were prepared by the help of the scale developed by Muncy and Vitell (1992). The results \\
\hline Accepted 25 June 2021 & $\begin{array}{l}\text { have been analyzed with SPSS and AMOS statistics programs. Frequency analysis, reliability analysis, } \\
\text { explanatory factor analysis, confirmatory factor analysis and structural equation model analyses have } \\
\text { been used. }\end{array}$ \\
\hline
\end{tabular}

Article Classification:

Research Article
Findings - The findings suggest that the level of moral maturity has a significant and negative effect on both unethical consumer behavior dimensions: "actively benefiting from an illegal situation" and "benefiting from actions perceived as harmless".

Discussion - Moral maturity refers to the assimilation of moral principles, the evaluation of moral rules by the conscience, and the realization of actions in this direction. People who have reached the level of moral maturity are expected to display ethical behaviors in the society in daily life. According to the findings of the research, as the moral maturity of the individual increases, the possibility of exhibiting unethical behavior decreases; as the moral maturity decreases, the possibility of unethical behavior increases. The results obtained show how effective the concept of morality on ethical consumer behavior is. Marketing managers should consider the moral maturity of consumers in order to understand their unethical behaviors. In this direction, activities (such as training, seminars, public spots, education for children) can be carried out to increase the level of moral maturity of consumers. Besides this, marketing managers can prevent unethical consumer behaviors by applying different marketing strategies (in the conclusion section, the recommendations are mentioned in detail) to consumers with low/high moral maturity level.

\section{Introduction}

Today, consumption has become a multidimensional concept that affects the whole world and shapes the social structure both economically, psychologically and socio-culturally. In today's societies named as "consumption society", consumers see consumption as an end rather than a tool. This situation directs consumers' relations with each other and with companies through their selves, and can lead to the emergence of hedonistic individuals who can enjoy only through consumption. This process makes it an obligation to consider the ethical principles necessary in all areas of life in terms of consumption. Ethic can be expressed as individuals, groups, companies or society choosing the good / right / appropriate / ethical and shaping their behavior in this direction. Companies have ethical responsibilities such as preparing their marketing strategies in an environmentally friendly manner, not implementing misleading or deceptive marketing activities or communicating all risks related to the product to the consumers. However, in order for consumers to be aware of their social responsibilities, they should also adopt and apply ethical principles. Unethical consumer behaviors such as purchasing products without paying their fees, trying to return or exchange by sharing false information, paying a lower price than the value of the product, using counterfeit/pirated products are among

\section{Önerilen Atıf/ Suggested Citation}

Sargın, S., Leblebici Koçer, L. (2021). An Investigation of the Effect of Moral Maturity on Consumer Ethics, Journal of Business ResearchTurk, 13 (2), 1764-1780. 


\section{S. Sargın - L. Leblebici Koçer 13/2 (2021) 1764-1780}

the important problems encountered in today's marketing world. Unethical behaviors of consumers also negatively affect the profitability levels of businesses (Levin et al., 2004: 48). For this reason, it is also important to investigate the unethical behaviors of consumers, the causes and consequences of these behaviors or the factors that affect these behaviors, apart from investigating the ethical behaviors of businesses. Because consumers have the responsibility to act in a way that will cause the least harm to the environment and society in the purchasing, use and post-purchase periods.

It is thought that the concept of morality will also be effective on the ethical / unethical behavior of consumers. Moral rules are the rules that regulate the relationships of individuals with society. If a negative comment is made about an individual's actions, it means that the action will have harmful consequences; if a positive comment is made, it will be appreciated by other individuals or the individual will be accepted by people. In other words, morality is defined as some spiritual characteristics that cause people to be evaluated as right or wrong and all of the behaviors they perform with their effect (Çağrıc1, 1989). The actions that emerge as a result of many factors such as the characteristics of the individual, the experiences he/she has acquired, lifelong learning, reason and will are expressed as the subject of morality. The morality level of the actions that occur as a result of characteristics that differ from individual to individual may also vary from person to person. The work of developmental psychologists is also similar to the philosophers' assessment of morality. For example, Kohlberg, famous for his work on moral development, explained moral development by dividing it into levels. Stating that people have different levels of moral development, Kohlberg stated that very few people reach the highest level of moral development. This stage, which is stated as the highest point, is expressed as the level of moral maturity. Because in the dictionaries of moral maturity, education and psychology, it is defined as the level of development required for a person or a society to make logical decisions about good and bad behavior according to moral rules (Bakırcioğlu, 2012). In this respect, it can be said that the level of moral maturity means the ability to behave in a rational and ethical way in moral matters. In other words, determining the level of moral maturity that has an effect on the behavior of the person is very important in terms of understanding the individuals and their actions.

When the studies in the literature are examined, it is seen that there are many factors such as personality traits (machiavellianism, narcissism, materialism and idealism), attitudes, beliefs and demographic characteristics that affect the unethical behavior of consumers. It is thought that one of the factors affecting unethical consumer behavior is the moral maturity of individuals. In previous studies, the relationship between consumer ethics and moral identity was examined (Vitell et al., 2016; Rodriguez-Rad ve Hidalgo, 2018; Chowdhury ve Fernando, 2014). Kavak et al. (2009) examined the effect of self and moral development levels on the ethical attitudes of consumers and measured the moral development using the "Values Identification Test (DIT)" developed by Rest (1979). In this study, the moral maturity of the participants have been examined and the scale which was adapted to Turkish culture and re-developed by Şengün and Kaya (2007) was used. Therefore, the purpose of this study is to examine the effect of moral maturity on consumer ethics. Since the relationship between moral concepts and consumer ethics is seen inadequate in the literature, it is expected that the study will contribute to the literature.

Research questions can be defined as: "Does the level of moral maturity have a meaningful and negative impact on unethical consumer behavior?" In the study, data will be collected by applying the online survey method to the sample group determined from consumers residing throughout Turkey using the convenience sampling method. The data obtained as a result of the survey study was analyzed using the SPSS and AMOS statistical package program and hypotheses were tested using structural equation modeling.

In this context, first of all, the concepts of moral maturity and consumer ethics will be emphasized in the study. Then the method of the research, the analysis of the data, the findings of the research, the evaluation of the findings and the conclusion section will be included.

\section{Conceptual Framework}

\subsection{Moral maturity}

The word "moral" is used in Western sources, which correspond to the concept of "morality". The word "moral" means "moralis" in Latin, character, state, custom and mode of action. According to the dictionary of Longman (Summers, 1995), the concept of "moral" is the difference between right and wrong; it is defined as the complete principles of what the actions called good and bad are made of and the ability to perceive the 


\section{S. Sargın - L. Leblebici Koçer 13/2 (2021) 1764-1780}

difference between right and wrong. According to Islamic philosophy, the concept of morality is primarily regarded as a virtue and competence. In this context, Ghazali explains the concept of morality as: "Morality is an ability established in the soul, from which the actions come easily without the need for intellectual coercion." (Kılıç, 2007). Ibn-i Sina, on the other hand, expressed morality as a spiritual virtue as well as being of religious origin. It is defined by Çağrıcı (1989) as spiritual qualities, temperament and voluntary behaviors that occur as a result of these, which cause people to be evaluated as true or false.

The concept of moral maturity is defined as all of the moral qualities that provide the status of being sufficient in terms of moral attitudes and actions. The concept of moral maturity can also be explained by using the concept of moral development. As a result of the learning and maturation processes of individuals throughout their lives, it is expected that the developing individuals will reach the maturity level. When the characteristics of a person who has reached the level of moral maturity are evaluated, it is expected to be a responsible, just, respectful, trustworthy, self-disciplined, right person with empathy, and above all, a good citizen who attaches importance to rules (Şengün and Kaya, 2007: 52).

In the light of all this information, it is expressed as the highest level of moral maturity that a person can reach in the development of his moral side. Moral maturity is a quality that requires adherence to the moral values that a person internalizes even when he is alone, regardless of time and conditions. Individuals who have reached a level of moral maturity are considered to be reliable, respectful, self-controlled, aware of their behavior, have high empathy skills, and can act with a sense of conscience when confronted with an immoral event.

When the studies in the literature on moral maturity are examined, it is seen that this concept is explained through the "Moral Development Theory" of Lawrence Kohlberg. The moral value judgment levels put forward by Kohlberg are also expressed as moral maturity (Şengün, 2008: 87). Kohlberg studied moral development by dividing it into some processes. In this direction, the moral development process has been handled in three levels: including the reactions of people to certain events, the pre-conventional level where rules are determined by other individuals, the traditional level where the expectations and wishes of the family and society are prioritized, and the post-conventional level where the person chooses moral principles independently of other individuals and society and presents a unique belief system (Çekin, 2013: 1036; Senemoğlu, 2011).

The first of the moral development processes is called the "pre-conventional" level. At this level of moral development, there is a commitment to authority and individuals act according to the punishment and reward system of the external authority (society). The second level of moral development is expressed as the "traditional" level. It is a process in which a person absorbs and accepts the value judgments and moral rules of the society with his family. According to this kind of moral understanding, obeying social rules is not enough, maintaining this order is of great importance (Şengün and Kaya, 2007: 51-64). The third and final level of moral development is the "post-conventional" level. In this process, a person accepts moral rules, but reshapes these rules in line with his own thoughts. It is the level of moral development dominated by the idea that social value judgments can change and can be shaped by differing from person to person. According to Kohlberg, the vast majority of individuals are at the second level of "traditional morality" in terms of moral maturity. It is seen that a small number of people can move to the third level of moral development, "postconventional" morality. According to Kant, achieving the highest level of moral maturity requires the ability to evaluate behavior according to universal value judgments (Habermas, 1982: 150).

From this point of view, it is possible to mention that people who have reached the highest moral development level by completing their moral development processes have reached the highest moral maturity. In this context, moral maturity is a state of being a right person, equipped and at the highest level in terms of moral feelings, judgments, thoughts, attitudes and behaviors, opposed to all immoral events, and developed the ability to empathize (Şengün and Kaya, 2007: 52).

\subsection{Consumer Ethics}

Ethics is expressed as all of the principles that enable the decisions of individuals or groups to be right or wrong, and to reveal which actions should or should not be done. In short, ethics is a branch of science that investigates social principles, good or bad, right or wrong behaviors from a moral aspect (Ertuhan and Filizöz, 


\section{S. Sargın - L. Leblebici Koçer 13/2 (2021) 1764-1780}

2011: 140). In other words, ethics can be defined as a moral guide that exists in all areas of individuals' lives and shows correct behavior. In this direction, it has become an inevitable situation to investigate consumption and consumer behavior in terms of ethical standards, which have been included in our lives since the day humanity existed.

Ferrell and Gresham (1985: 89) emphasized the necessity of ethical principles in the marketing world and revealed that there are two different ethical approaches in consumer behavior, teleologically and deontologically. In the study conducted by Hunt and Vitell (1986: 6), the deontological approach is defined as a process in which consumers question their behavior in line with true and false moral values; teleological approach is expressed as a process in which consumers evaluate the consequences of their behavior. According to the deontological approach, it is thought that innate personality traits shape the behavior of consumers and social values can have a significant effect on consumer behavior (Torlak, 2009: 125). In the teleological approach, the moral aspect of the actions of consumers is determined according to the results of these actions (Ferrell and Gresham, 1985: 89). In summary, the deontological approach is the intention that causes the action; teleological approach refers to the evaluation of the result of the action.

Muncy and Vitell (1992: 298) made the generally accepted definition in the field of consumer ethics. They express consumer ethics as moral rules and standards that guide the behavior of individuals or groups to purchase, use and consume products. In this context, ethical consumers are defined as consumers who carry out purchasing processes and exhibit ethical consumption behavior by considering ethical standards during the consumption act (Erciş and Türk, 2016: 3). In their study, Muncy and Vitell (1992: 298) examined whether there is a relationship between the ethical attitudes and behaviors of consumers and their socio-demographic characteristics. They developed the Ethical Consumer Scale, and stated that consumer behavior consists of four dimensions that can be ethically defined as true or false Muncy and Vitell (1992):

- Actively Benefiting from Illegal Activities: It refers to the consumers who consciously benefit from illegal activities. Behaviors such as changing the label of the product, eating and drinking at the market without paying the price, showing the damaged product due to his/her own fault as pre-damaged represent this factor.

- Passive Utilization of a Situation at the Expense of Others: This dimension represents consumers who deliberately remain silent and ignore unethical behavior. Behaviors such as staying silent despite the excessive change, giving false information about the age of the child in order to obtain a discount represent this factor.

- Benefiting from a Partially Harmless Action: This factor represents consumers who think their wrongdoing will go unnoticed. Behaviors such as using expired discount coupons, making a false statement in income, benefiting from tax payments, and saying that the purchased product is a gift when returning to the store represent this factor.

- Benefiting from Action Perceived as Harmless: It refers to the consumers who do not see their behavior as harmful. Behaviors such as using copied computer software, recording movies on TV, not purchasing products even though they have been tried, and using a copy without buying a music album represent this dimension.

The original Ethical Consumer Scale, which was developed by Muncy and Vitell (1992) consists of 4 subdimensions and 18 statements. But the Turkish version of the scale was rearranged and adapted by Saray and Hazer (2017), there are 2 factors and 8 statements (Saray and Hazer, 2017:258). These 2 factors are "active exploitation of an illegal situation" and "benefiting from acts perceived as harmless". Unethical behaviors in consumer ethics literature consist of different dimensions; consumers' acceptance of a behavior and maintaining this behavior is the "active use"; the extent to which consumers gain from unethical behavior of others, "passive exploitation"; the dimension of benefiting from the controversial and contradictory situations that consumers make appears as "active utilization of controversial open issues" and "the dimension of damage / deceit" in order for consumers to take advantage of opportunities (Erciş et al., 2017:232).

Wilkes (1978) found that unethical consumer behaviors were negatively evaluated by the participants. Forsyth (1980) discussed ethical ideologies in two groups as relativists and idealists. While making ethical evaluations, relativists oppose universal value judgments and emphasize the importance of different conditions. Idealists are unconditionally bound to moral values. Studies in the literature mostly examine the relationship between 


\section{S. Sargın - L. Leblebici Koçer 13/2 (2021) 1764-1780}

ethical ideologies and ethical consumer behavior (Rawwas et al. 1995; Al-Khatib et al. 1995; Al-Khatib et al.1997; Erffmeyer et al.1999; Rawwas, 2001; Swaidan et al. 2003; Lu and Lu, 2010; Arli and Pekerti, 2016). Muncy and Vitell (1992) found in their research that consumers who have a positive attitude towards businesses tend to behave more ethically and that older, less educated and lower-income consumers have higher ethical sensitivity.

Al-Khatib et al. (1995) examined the relationship between 4 sub-dimensions of the Ethical Consumer Scale and idealism, relativism and machiavellianism. Al-Khatib et al. (1997) state that consumers with a higher education level exhibit more ethical behaviors and that cultural differences have an impact on ethical behaviors. Using the same scale, Chan et al. (1998) found that consumers make similar ethical evaluations in the face of a certain event, despite cultural differences. In his work in Turkey, Yurtsever (1998) examined the relationship between ethical consumer behavior, machiavellianism, ethical ideology and ethical beliefs and concluded that Turkish consumers are very sensitive to ethical issues. Erffmeyer et al. (1999) found that female consumers were less inclined to accept illegal activities than male consumers, students were more likely to manipulate others in order to achieve their personal interests, and that there was no relationship between education level and consumer ethics. Varinli (2000), in his study with university students, states that demographic factors such as education level, profession, family income are effective on unethical consumer behavior. In the study carried out by Kavak (2001), it was revealed that there is an inverse relationship between the level of machiavellianism and ethical perception of consumers. Rawwas (2001:203), in his study examining the relationship between consumers' ethical beliefs and machiavellian personality traits, states that Irish, USA and Australian consumers, who have materialist characteristics, are more pragmatic in terms of ethical rules, while Egyptian and Lebanese consumers have collective beliefs.

Oyman (2004) found that the age, gender and marital status of consumers are not related to ethical perception, but that there is a significant relationship between education level and the ethical perception. However, it has been concluded that the respondents have high levels of sensitivity in ethical issues, except for "actions perceived as harmless". Ecer (2006) states that age and education level are positively associated with consumer ethics and gender, income, occupation and marital status have no effect on the formation of consumer ethics. Kavak et al. (2009) examined the relationship between self, self-monitoring, moral development and consumers' ethical attitudes, and concluded that the level of moral development and self-monitoring have an effect on consumers' ethical attitudes.

Torlak and Tiltay (2009) state that low-income consumers have more unethical behavior orientations. However, significant relationships have been identified between materialist trends, religious values and consumer morality. Hazer (2012) found that single consumers exhibit unethical behaviors at a higher rate. At the same time, it was observed that the participants had a high machiavellian tendency and they were more idealistic and less realistic. Hazer and Öztürk (2013) concluded that older consumers with higher income have higher perceptions of consumer ethics. Vitell et al. (2016) found in their study that as the level of internalization of moral identity increases, the ethical tendencies of consumers also increase. Arli and Pekerti (2016) found that religious consumers have higher ethical values compared to non-religious consumers. Masuda et al. (2019) state that the higher the likelihood of charitable donations, the higher the positive attitude of consumers towards ethical products. As a result of the study conducted by Özden (2019), it was seen that consumers' ethical behaviors and brand-oriented decision-making styles differ according to their demographic characteristics.

Oyman (2004: 79-80) examines the studies in the literature on consumer ethics in four groups. These studies consist of the topics such as examining the consumers' stealing behaviors in stores, consumers' decisionmaking process and the factors that influence this process, consumers' ethical perception of the actions of businesses and cross-cultural comparisons in consumer ethics. According to these studies, factors such as values, attitudes, morality, personality traits, self-esteem, Machiavellianism, needs, idealism, relativism and ethical ideologies influence consumers ' ethical buying behavior.

When studies in the literature are examined, one study has been found that examines the effect of moral maturity on consumers' unethical behaviors. Kavak et al. (2009) examined the effect of self-monitoring and moral development levels on consumers' ethical attitudes. However, in the study, the level of moral development was measured through the "Determination of Values Test (DIT)" developed by Rest (1979). In 


\section{S. Sargın - L. Leblebici Koçer 13/2 (2021) 1764-1780}

this study, not the moral development but the moral maturity of the participants have been examined through the scale adapted to Turkish culture and redeveloped by Şengün and Kaya (2007). When the studies in foreign literature are examined, it is seen that, Vitell et al. (2016), Rodriguez-Rad and Hidalgo (2018) and Chowdhury and Fernando (2014) investigated the effect of moral identity on ethical consumer behavior. However, studies examining the relationship between moral maturity and consumer ethics in the literature are inadequate. In this direction, the study is expected to contribute to the literature. In the light of these studies examining the relationship between consumer ethics and morality, the hypotheses of the research were formed as follows: $\mathrm{H}_{1}$ : Moral maturity has a significant and negative effect on "actively benefiting from an illegal situation" dimension of unethical consumer behavior.

$\mathbf{H}_{2}$ : Moral maturity has a significant and negative effect on "benefiting from actions perceived as harmless" dimension of unethical consumer behavior.

\section{Methodology}

\subsection{Research Model}

The research model of this study examines the effect of moral maturity on consumer ethics dimensions ("actively benefiting from an illegal situation" and "benefiting from actions perceived as harmless"). The research model is shown in Figure 1.

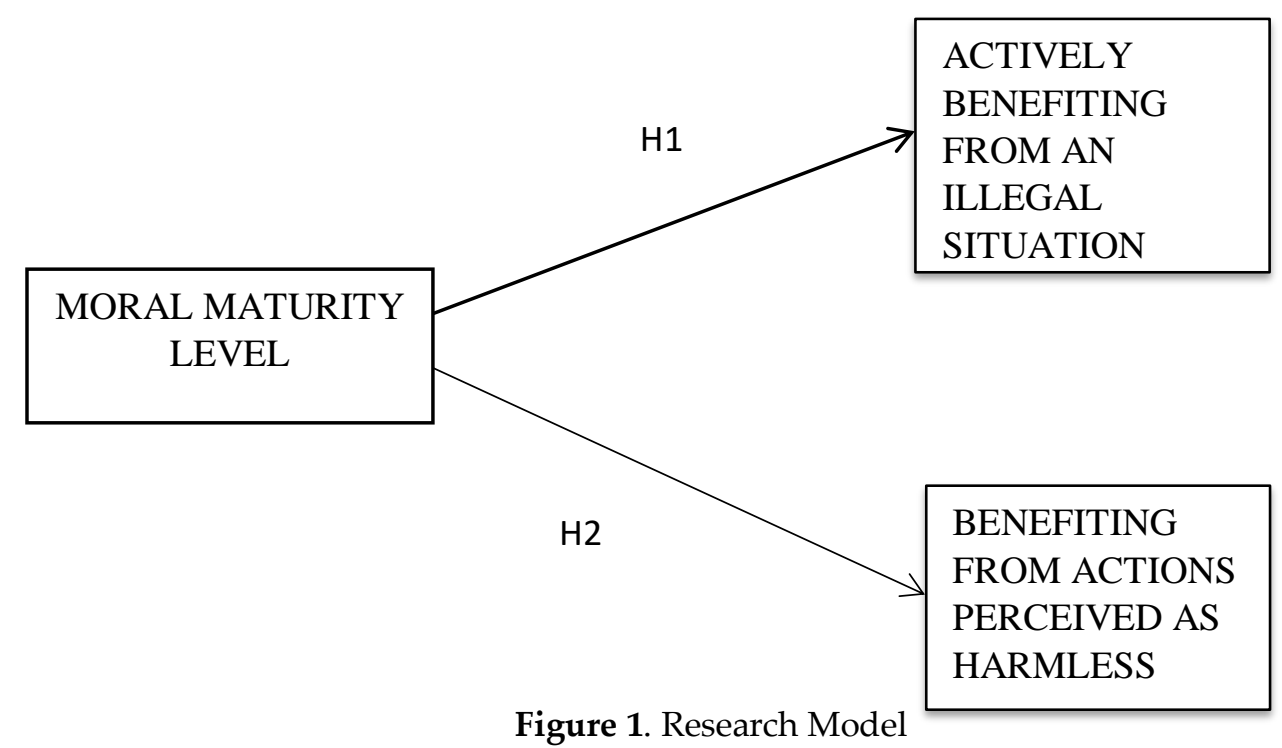

\subsection{Research Sample and Data Collection Method}

The universe of this descriptive research consists of consumers living in Turkey. While creating the sample, "convenience sampling" method was used. The sample size was determined according to Yazıcığlu and Erdoğan (2004) sample sizes table. According to the table, it is stated that at least 384 people can be included in the sample for a population of 10 million and more. In this quantitative study, a survey was conducted on 457 consumers. The online survey method was used in the study, and the survey was conducted over the Google Form application. The survey technique is used by many researchers to obtain first-order information. This technique is the most preferred method for data collection. Features such as reaching more people in a short time, being an economic data collection technique, and accessing the obtained data quickly play a role in this (Yazıcıoğlu and Erdoğan, 2004:51). The survey was conducted between 01.03.2021 and 01.04.2021, after the Ethics Committee Approval Certificate dated 23.02.2021 and numbered 77 was obtained from Erciyes University Social and Human Sciences Ethics Committee. An "Informed Consent Form" was presented to the participants and they were informed that participation in the survey application is completely voluntary.

\subsection{The Scales Used in the Research}

The questionnaire form consists of 3 parts. In the first part, there are 4 statements to determine the demographic characteristics of the participants such as age, gender, education and income level. The second 
part includes 66 statements for measuring moral maturity and the third part includes 18 statements for measuring the unethical behaviors of consumers. While creating the questionnaire, moral maturity statements were prepared by using the scales developed by Şengün and Kaya (2007), and the consumer ethics statements were prepared by the help of the scale developed by Muncy and Vitell (1992). Reliability analysis was made for all the scales. After that, the confirmatory factor analysis and convergent-divergent validity analysis were performed for testing the validity of the scales and the results are shown in Table 2, Table 7 and Table 8. For the purpose of providing convenience during answering questions and in the analysis to be done, the expressions of the moral maturity and ethical consumer scales were prepared using a closed-ended and 5point Likert scale.

\subsection{Data Analysis}

In order to analyze the research data, first of all, the reliability analysis of the scales used in the research was made. Then, descriptive statistics regarding the demographic characteristics of the participants and the expressions in the questionnaire form were included. Explanatory factor analysis was conducted in order to determine the factors that are effective in evaluating the expressions of the respondents about unethical consumer behavior and moral maturity. Confirmatory factor analysis was conducted to test whether there was a sufficient relationship between the determined factors and whether the factors explained the model sufficiently. In order to test the hypotheses of the research, the Structural Equation Model was used. Structural equation modeling (SEM) is frequently used by scientists to test the relationships between observed and latent variables (Hoyle, 1995). The intensive use of SEM in many different areas is due to the fact that it takes into account the measurement errors of the observed variables different from traditional methods (Schumacker and Lomax, 2004). Another reason why SEM is widely used in scientific research is that it allows to develop, predict and test multivariate models that include both direct effects from one variable to another, and indirect effects between two variables, caused by the effect of a mediator variable (Raykov and Marcoulides, 2006). In order to test the direct effect of moral maturity on the unethical consumer behavior, Structural Equation Model has been used in this study. Descriptive statistics, reliability analysis and explanatory factor analysis were analyzed through SPSS; confirmatory factor analysis and hypothesis testing were analyzed through the AMOS statistical program.

\subsection{Findings and Evaluation of the Research}

The analyzes made and the findings obtained in the research are given and interpreted in the relevant tables below.

\subsubsection{Descriptive Statistics Findings Regarding Demographic Features}

The frequency and percentages regarding the demographic characteristics of the participants are given in Table 1.

Table 1. Distribution by Demographic Characteristics

\begin{tabular}{|c|c|c|c|c|c|c|c|}
\hline \multicolumn{2}{|c|}{ Demographic features } & \multirow{2}{*}{$\begin{array}{l}\mathbf{n} \\
174\end{array}$} & \multirow{2}{*}{$\begin{array}{l}\% \\
38,1 \\
\end{array}$} & \multicolumn{2}{|c|}{ Demographic features } & \multirow{2}{*}{$\begin{array}{l}\mathbf{n} \\
331\end{array}$} & \multirow{2}{*}{$\begin{array}{l}\% \\
72,4 \\
\end{array}$} \\
\hline \multirow{7}{*}{ Age } & 26 and less & & & \multirow{3}{*}{ Gender } & Male & & \\
\hline & $27-32$ & 60 & 13,1 & & Female & 123 & 27,6 \\
\hline & \begin{tabular}{|l|}
$33-38$ \\
\end{tabular} & 71 & 15,5 & & Total & 457 & 100 \\
\hline & $39-44$ & 67 & 14,7 & \multirow{7}{*}{$\begin{array}{l}\text { Education } \\
\text { Status }\end{array}$} & Primary School & 5 & 1,1 \\
\hline & $45-50$ & 29 & 6,3 & & Middle School & 6 & 1,3 \\
\hline & 51 and more & 56 & 12,3 & & High School & 43 & 9,4 \\
\hline & Total & 457 & 100 & & $\begin{array}{l}\text { Associate's } \\
\text { Degree }\end{array}$ & 28 & 6,1 \\
\hline \multirow{6}{*}{ Income (TL) } & 2000 and less & 106 & 23,2 & & Undergraduate & 280 & 61,3 \\
\hline & 2001-3000 & 62 & 13,6 & & Graduate & 95 & 20,8 \\
\hline & $3001-4000$ & 42 & 9,2 & & Total & 457 & 100 \\
\hline & $4001-5000$ & 89 & 19,5 & & & & \\
\hline & 5001 and more & 158 & 34,6 & & & & \\
\hline & Total & 457 & 100 & & & & \\
\hline
\end{tabular}




\section{S. Sargın - L. Leblebici Koçer 13/2 (2021) 1764-1780}

When the distribution of the participants according to their demographic characteristics is examined, $72.4 \%$ of the 457 consumers participating in the study are women, $27.6 \%$ are men; $38.1 \%$ of them are under 26 years old; $34.6 \%$ of them have an income of $5001 \mathrm{TL}$ and above, $23.2 \%$ of them have an income of $2000 \mathrm{TL}$ and below; $61.3 \%$ of them graduated from undergraduate programs. Following the frequency analysis to examine demographic characteristics, reliability analysis was performed for the scales used in the study.

Table 2. Reliability Values of the Scales Used in the Study

\begin{tabular}{|l|c|}
\hline Scales & Cronbach Alpha Coefficient \\
\hline Moral Maturity Scale &, 868 \\
\hline Ethical Consumer Scale &, 815 \\
\hline
\end{tabular}

When the Alpha coefficients obtained as a result of the reliability analysis are examined, it is concluded that the moral maturity and unethical consumer behavior statements in the questionnaire form are highly reliable. To say that the scales are reliable, an Alpha value of 0.70 and above is considered sufficient (Nunnally, 1978).

\subsubsection{Explanatory Factor Analysis}

In order to determine the factors that affect the participants' evaluations regarding the expressions in the questionnaire, an explanatory factor analysis was applied to both the moral maturity statements and the unethical consumer behavior statements.

3.5.2.1. Determining the Factors Effective in Evaluating the Expressions of Respondents about Unethical Consumer Behavior

"Factor analysis is a type of multivariate analysis that provides a more meaningful summary of the data based on the relationships between a group of variables. Factor analysis, which is a kind of classification method, examines the relationships between variables and helps to transform them into less number of variables (Nakip, 2003: 403). Before the explanatory factor analysis, KMO (Kaiser-Meyer-Olkin) and Bartlett's Test were conducted to determine whether the data were suitable for factor analysis. $\mathrm{KMO}$ and Barlett Test results are shown in Table 3.

Table 3. KMO and Bartlett's Test Results

\begin{tabular}{|l|l|c|}
\hline Kaiser-Meyer-Olkin Measure Sample Fit Test & ,859 \\
\hline \multirow{3}{*}{ Bartlett's Test } & Approximate Chi-Square & 2093,615 \\
\cline { 2 - 3 } & df & 153 \\
\cline { 2 - 3 } & Sig. &, 000 \\
\hline
\end{tabular}

The KMO value, which is an indicator that evaluates the suitability of the factor analysis, shows that it is within acceptable limits (Altunışı et al., 2005: 217). The KMO (Kaiser-Meyer-Olkin Measure Sample Fit Test) test result was found to be ,859. Accordingly, it can be stated that the sample, for which factor analysis is applied, is a sufficient sample. Barlett's test result is $x^{2}=2093,615$ and it explains that there is a relationship between variables in the population at the ,000 significance level. Factor analysis was carried out in order to gather the expressions of unethical consumer behaviors of the survey respondents under a certain number of factors. However, when the factor loads were evaluated, it was seen that the factor loads of some expressions were below 500, and it was concluded that the correlation coefficient of these expressions was also low. For this reason, 4 statements from ethical consumer scale statements were excluded from the analysis and factor analysis was applied to the remaining statements. 
Table 4. Factors Affecting Respondents' Assessment of Expressions Regarding Unethical Consumer Behaviors

\begin{tabular}{|c|c|c|c|c|}
\hline Factors & Eigenvalue & $\begin{array}{l}\text { Variance } \\
\text { Explained }\end{array}$ & $\begin{array}{l}\text { Factor } \\
\text { Loadings }\end{array}$ & $\begin{array}{l}\text { Reliability } \\
\text { Coefficients }\end{array}$ \\
\hline $\begin{array}{l}\text { Factor 1: Actively Benefiting from an Illegal } \\
\text { Situation }\end{array}$ & 5,061 & 48,116 &, 548 & ,805 \\
\hline I change the price tag on the item in the store. & & & ,666 & \\
\hline $\begin{array}{l}\text { Since he/she does not know the price of the product, I } \\
\text { tell the cashier that asks me the price of the product is } \\
\text { low. }\end{array}$ & & &, 564 & \\
\hline $\begin{array}{l}\text { I say nothing even though I realize the cashier } \\
\text { overpays. }\end{array}$ & & & 642 & \\
\hline $\begin{array}{l}\text { I eat a pack of chocolates without paying when } \\
\text { shopping at the supermarket. }\end{array}$ & & & ,711 & \\
\hline $\begin{array}{l}\text { I show my lost property to the insurance company as } \\
\text { stolen to get money. }\end{array}$ & & &, 595 & \\
\hline $\begin{array}{l}\text { I won't say anything if I find that the waiter has } \\
\text { calculated the bill low. }\end{array}$ & & & ,565 & \\
\hline $\begin{array}{l}\text { I lie about the age of the child to take advantage of the } \\
\text { reduced price. }\end{array}$ & & & ,608 & \\
\hline $\begin{array}{l}\text { I taste the products without buying anything from the } \\
\text { supermarket. }\end{array}$ & & &, 520 & \\
\hline \multicolumn{5}{|l|}{$\begin{array}{l}\text { Although I wear the dress I bought from the store one } \\
\text { day, I take and return it the next day }\end{array}$} \\
\hline $\begin{array}{l}\text { Factor 2: Benefiting From Actions Perceived As } \\
\text { Harmless }\end{array}$ & 1,845 & 63,126 &, 541 & ,716 \\
\hline $\begin{array}{l}\text { To avoid miscellaneous costs, I will put my second- } \\
\text { hand car down for a lower price. }\end{array}$ & & & ,638 & \\
\hline $\begin{array}{l}\text { In the bank, post office, etc. I'd do it right away with } \\
\text { someone familiar rather than waiting in line. }\end{array}$ & & & 694 & \\
\hline $\begin{array}{l}\text { I use a computer program or game even though I } \\
\text { haven't purchased it }\end{array}$ & & & 623 & \\
\hline $\begin{array}{l}\text { Thinking that the VAT voucher will not work for me, } \\
\text { I make a discount on the price. }\end{array}$ & & & 796 & \\
\hline I copy instead of buying a music album, cd, etc. & & & & \\
\hline
\end{tabular}

Two factors (perceived value dimensions) with eigenvalues greater than 1 were revealed as a result of explanatory factor analysis. Factors with an eigenvalue greater than 1 explain $63,126 \%$ of the total variance. The explanation of $2 / 3$ of the total variance of the variables in the analysis is considered appropriate (Bayram, 2009:200). Reliability analysis has been performed to measure whether the statements are consistent with each other and the reliability coefficients are included in the table. The contents of the two factors were determined according to the results of the factor rotation (Rotated Component Matrix), which enables the two factors revealed by factor analysis to be easily defined in terms of the variables they contain. The two factors obtained by taking into account the variables that make up the factors are named as "actively benefiting from an illegal situation" and "benefiting from actions perceived as harmless". The dimensions obtained are similar to the dimensions of the ethical consumer scale developed by Saray and Hazer (2017). Factor loads of all variables are over 500, and when the variables that contribute to the factors are examined, it is seen that they are related to the factors. When the Alpha coefficients obtained as a result of the reliability analysis for the factors are examined, it is concluded that each factor obtained as a result of the factor analysis is highly reliable. Generally, an alpha value of 70 and above is considered sufficient (Altunış1k et al., 2005: 116). Factors, factor loads and reliability coefficients obtained as a result of the explanatory factor analysis are given in Table 4. 
3.5.2.2. Determining the Factors Effective in the Evaluation of the Expressions Related to the Moral maturity of the Respondents

KMO (Kaiser-Meyer-Olkin) and Barlett's tests were performed to test whether the data set was suitable for factor analysis. KMO and Barlett test results are given in Table 5.

Table 5. KMO and Bartlett's Test Results

\begin{tabular}{|l|l|c|}
\hline Kaiser-Meyer-Olkin Measure Sample Fit Test &, 951 \\
\hline Bartlett's Test & Approximate Chi-Square & 6145,609 \\
\cline { 2 - 3 } & df & 378 \\
\cline { 2 - 3 } & Sig. &, 000 \\
\hline
\end{tabular}

The KMO (Kaiser-Meyer-Olkin Measure Sample Fit) test result was found to be ,951. Accordingly, it can be stated that the sampling with factor analysis is a sufficient sample. The Barlett's test came out as $\mathrm{x}^{2}=6145,609$ and it was concluded that there was a relationship between the variables in the population at the level of ,000 significance. Factor analysis was applied to the expressions to measure the unethical consumer behavior of the respondents. In this scale, items with a factor load of less than 500 and overlapping items were determined and these items were excluded from the analysis.

Table 6. Factors Affecting Respondents' Assessment of Expressions Related to Moral maturity

\begin{tabular}{|l|l|l|l|l|}
\hline Factors & Eigenvalue & $\begin{array}{l}\text { Variance } \\
\text { Explained }\end{array}$ & $\begin{array}{l}\text { Factor } \\
\text { Loadings }\end{array}$ & $\begin{array}{l}\text { Reliability } \\
\text { Coefficients }\end{array}$ \\
\hline Factor 1: Moral maturity & 11,406 & 40,734 & &, 940 \\
\hline I make an effort to make others happy. & & &, 571 & \\
\hline I apologise when I misbehave. & & &, 532 & \\
\hline I respect the rights of others. & & &, 688 & \\
\hline I am sensitive to other people's feelings. & & &, 629 & \\
\hline I keep the environment clean. & & &, 659 & \\
\hline I respect the beliefs of others. & & &, 728 & \\
\hline I hesitate to hurt people. & & &, 639 & \\
\hline I treat adults with respect. & &, 585 & \\
\hline $\begin{array}{l}\text { I never compromise on righteousness and justice, I } \\
\text { am a fair person. }\end{array}$ & & &, 535 & \\
\hline I avoid arrogance and pride. & &, 575 & \\
\hline I am a humble person. & &, 662 & \\
\hline $\begin{array}{l}\text { I seek solutions to my problems with others within } \\
\text { the framework of compromise and peace. }\end{array}$ & & &, 665 & \\
\hline I imitate good people around me. & &, 664 & \\
\hline I pay attention to fulfill my responsibilities. & &, 706 & \\
\hline $\begin{array}{l}\text { I try to understand them by putting myself in } \\
\text { other people's shoes . }\end{array}$ & & &, 566 & \\
\hline I try to follow the counsel of my elders. & &, 829 & \\
\hline I take care not to break a heart. & &, 538 & \\
\hline I try to prevent those who do evil. & &, 510 & \\
\hline I try to reconcile the resenters. & &, 510 & \\
\hline I have mercy on the weak people. & &, 749 & \\
\hline I try to be consistent and balanced in my behavior. & & & & \\
\hline $\begin{array}{l}\text { I treat those around me with understanding and } \\
\text { tolerance. }\end{array}$ & & & & \\
\hline I wouldn't insult anyone. & & & & \\
\hline $\begin{array}{l}\text { I think about my behavior and try to correct my } \\
\text { wrong behavior. }\end{array}$ & & & & \\
\hline
\end{tabular}


S. Sargın - L. Leblebici Koçer 13/2 (2021) 1764-1780

\begin{tabular}{|c|c|}
\hline $\begin{array}{l}\text { I do not make a decision without thorough } \\
\text { research and understanding. }\end{array}$ &, 594 \\
\hline I act with accurate and correct information. & 604 \\
\hline I get along well with my neighbors. & 658 \\
\hline I don't be rude. & .662 \\
\hline
\end{tabular}

One factor (perceived value dimensions) with an eigenvalue greater than 1 was found through explanatory factor analysis. The single-factor structure obtained as a result of the factor analysis is similar to the structure obtained by Şengün and Kaya (2007). In the explanatory factor analysis, the total variance explained by all factors should be at least 30\% in one-dimensional scales (Gürbüz and Şahin, 2014). The factor loads of all the variables in the analysis are over 500, and when the variables that contribute to the factor are examined, it is seen that they are related to the factor. This factor, factor loadings and reliability coefficient are given in Table 6.

\subsubsection{Confirmatory Factor Analysis}

Confirmatory factor analysis is used to test whether there is a sufficient relationship between the determined factors and whether the factors explain the model sufficiently (Bayram, 2010). In this way, factor structures and loadings are examined and the validity of the scales in the questionnaire forms is tested. Confirmatory factor analysis was performed using the AMOS program with the dimensions determined according to the explanatory factor analysis. The analyzed model is included in Figure 2.

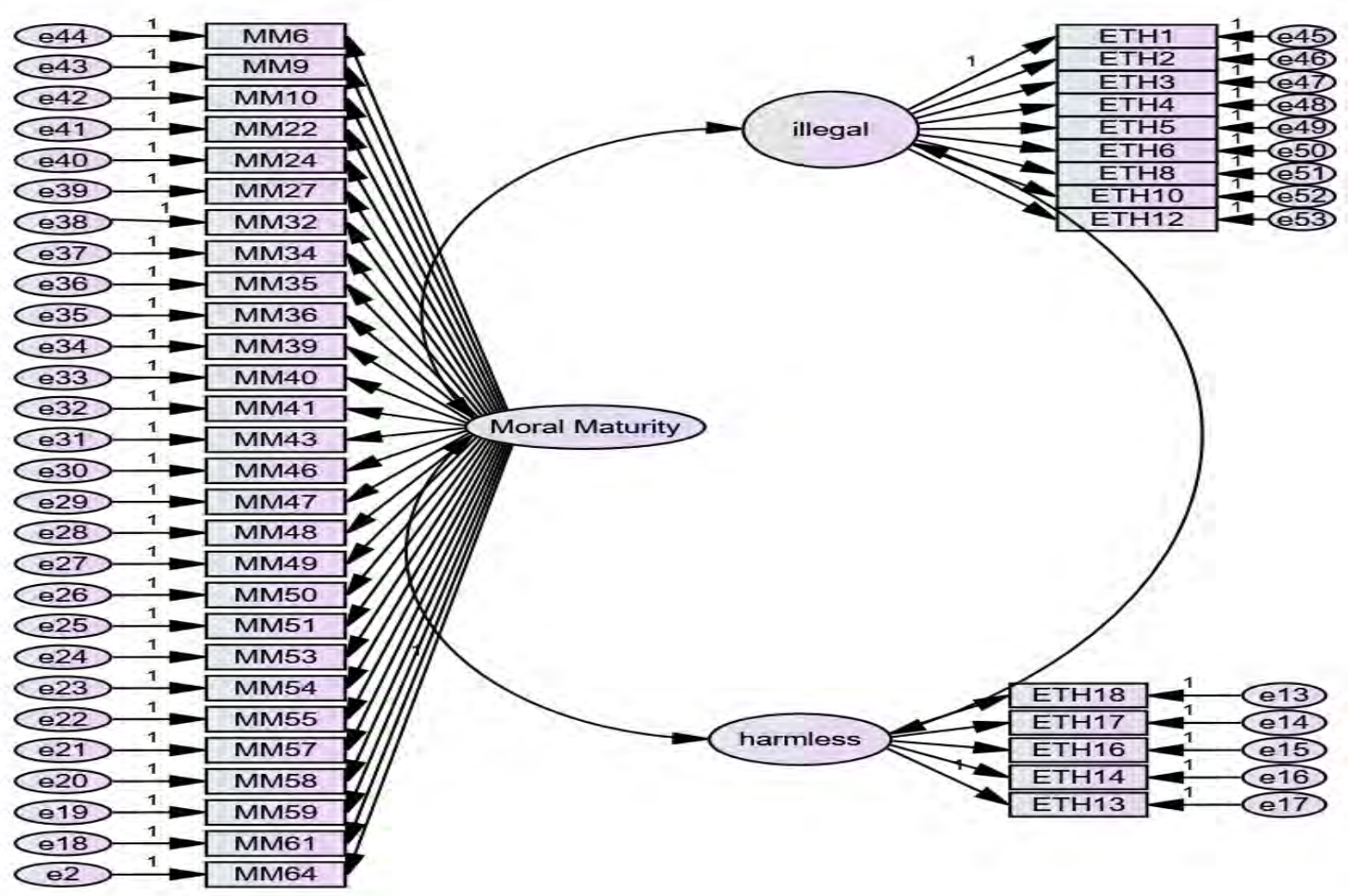

Figure 2. Confirmatory Factor Analysis Model

The goodness of fit values, research model and acceptable values obtained as a result of the measurement are given in Table 7. The acceptable limits of fit values have been obtained by benefiting from the studies of Bentler and Bonett (1980). 
Table 7. Examination of the Fit Between the Model and the Data

\begin{tabular}{|l|c|c|c|}
\hline Fit Indexes & Research Model & Accepted Values & Abbreviations \\
\hline $\mathbf{X}^{2}$ Value & 1381,765 &, 000 & CMIN \\
\hline Degree of Freedom & 786 & 0 & DF \\
\hline $\mathbf{P}$ &, 000 & $<, 005$ & $\mathrm{P}$ \\
\hline $\mathbf{X}^{2} / \mathbf{d f}$ & 1,758 & $<5$ & $\mathrm{CMIN} / \mathrm{DF}$ \\
\hline Adjusted Goodness of Fit Index &, 861 &, $85 \leq \mathrm{AGFI} \leq 90$ & $\mathrm{AGFI}$ \\
\hline Incremental Fit Index &, 925 &, $90 \leq \mathrm{IFI} \leq, 95$ & IFI \\
\hline Comparative Fit Index &, 924 &, $90 \leq \mathrm{CFI} \leq, 95$ & $\mathrm{CFI}$ \\
\hline Approximate Root Mean Square Errors &, 051 &, $05 \leq \mathrm{RMSEA} \leq, 08$ & RMSEA \\
\hline
\end{tabular}

One of the most important criteria that tests the compatibility of the model with the data is the chi-square statistic (Bayram, 2010). According to the measurement results, it is seen that the chi-square statistics are significant $(p=0.000)$. The standard chi-square value shows the ratio of the chi-square value to the degrees of freedom and was found to be 1,758 . If this value gives a result below 5 , it shows that the value is acceptable (Chen and Tsai, 2007). When the values of goodness of fit and acceptable values in Table 7 are examined, it is concluded that the data is compatible.

Table 8. Convergent and Discriminant Validity

\begin{tabular}{|l|c|c|c|}
\hline SCALE & AVE & CR & Cronbach's Alfa \\
\hline Actively Benefiting from an Illegal Situation & 0,506 & 0,808 &, 805 \\
\hline Benefiting From Actions Perceived As Harmless & 0,572 & 0,945 &, 716 \\
\hline Moral maturity & 0,489 & 0,721 &, 940 \\
\hline
\end{tabular}

To determine convergent and divergent validity of the model, analyzes were made and given in Table 8 . Identifying the convergence validity, the method determined by Fornell and Lacker in 1981 was used. According to this method, to ensure the convergence validity of the scale, the average variance extracted (AVE) values of the variables should be above 0.50 ; the composite reliability values (CR) should be above 0.70 (Hair et al., 2010: 723) However, if the CR value is greater than 0,70 when the AVE value is less than 0,5 then the analyzed AVE value can be accepted (Fornell and Lacker, 1981). Thus, it can be stated that the values in the table are at an acceptable level.

\subsubsection{Hypothesis Testing}

The Structural Equation Model was used to test the hypotheses of the research and the data were analyzed in the AMOS statistical package program. 


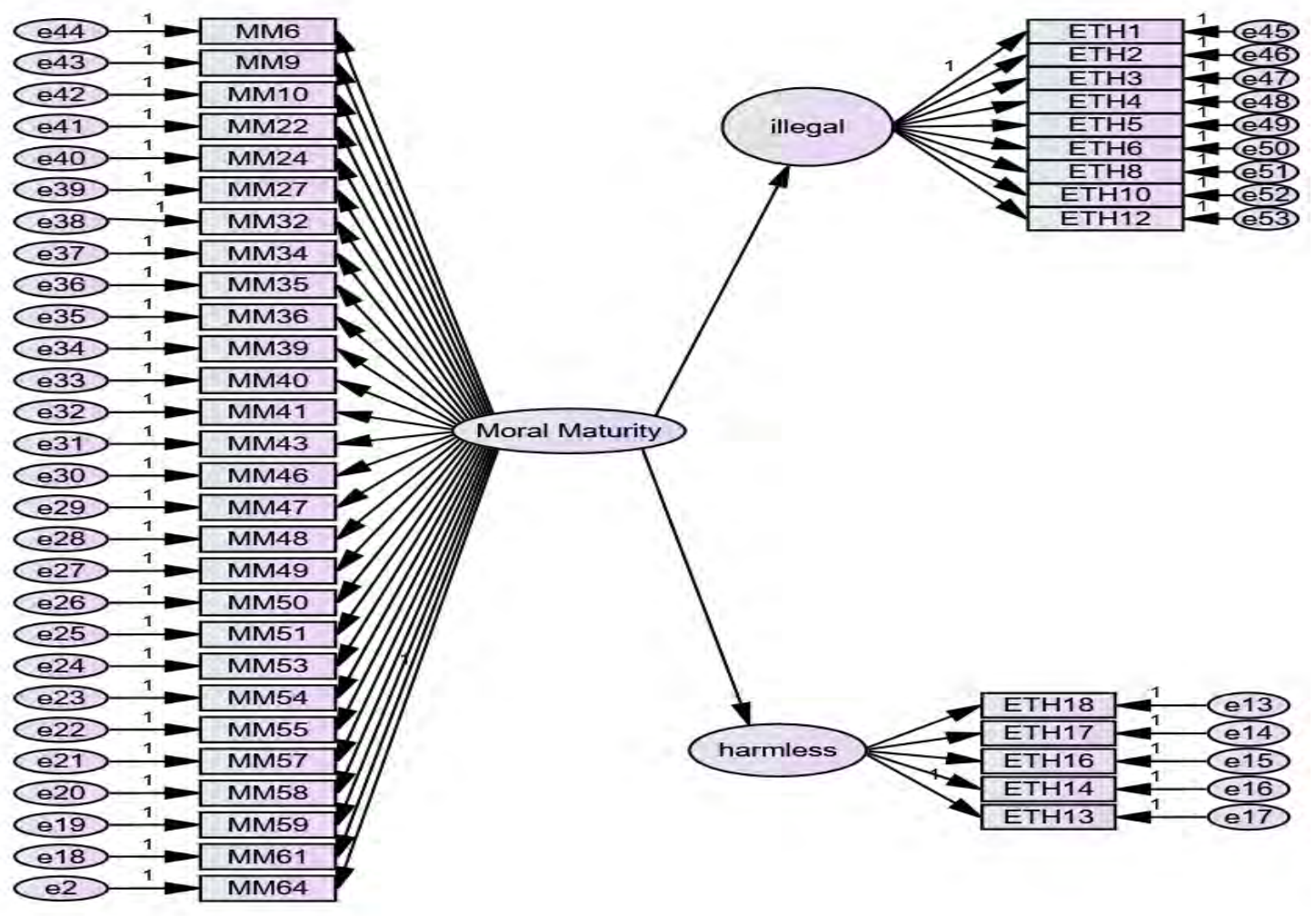

Figure 3. Structural Equation Model

The fit values and acceptable values resulting from the testing of the structural equation model shown above are presented in Table 9.

Table 9. Structural Equation Model Regression Coefficients Between Moral maturity and Unethical Consumer Behaviors

\begin{tabular}{|l|l|c|c|c|c|c|}
\hline & Variables & $\mathbf{R}^{2}$ & $\boldsymbol{\beta}$ & $\mathbf{t}$ & $\mathbf{P}$ & Result \\
\hline $\mathbf{H 1}$ & $\begin{array}{l}\text { Moral maturity } \\
\text { Actively Benefiting from an } \\
\text { Illegal Situation }\end{array}$ &, 021 & -047 & $-2,583$ &, 010 & Accept \\
\hline $\mathbf{H 2}$ & $\begin{array}{l}\text { Moral maturity } \\
\text { Benefiting From Actions } \\
\text { Perceived As Harmless }\end{array}$ &, 242 & -427 & $-6,678$ &, 000 & Accept \\
\hline $\begin{array}{l}\text { Structural Equation Model Goodness of Fit Values: } \\
\mathbf{X}^{2} \text { Value: 1471,120; } \mathbf{X}^{2 / d f: ~ 1,862 ; ~ R M S E A: ~, 053 ; ~ C F I: ~, 913 ; ~ A G F I:, 854 ; ~ I F I: ~, 914 ; ~ P=0,000 ~}\end{array}$
\end{tabular}

When the goodness of fit values of the model are examined, it is concluded that all values are within acceptable limits and the model is a valid model. When the values in the table are examined, it is seen that the level of moral maturity has a significant and negative effect on the dimension of actively benefiting from an illegal situation ( $\mathrm{p}<0.05 ; \beta$ : -,047; R2:,021). In this context, $\mathrm{H}_{1}$ : "Moral maturity has a significant and negative effect on 'actively benefiting from an illegal situation' dimension of unethical consumer behavior." was accepted. Besides, it is seen that the level of moral maturity has a significant and negative effect on the dimension of "benefiting from actions perceived as harmless" ( $\mathrm{p}<0.05 ; \beta$ : -,427; R2:,242). Accordingly, $\mathrm{H}_{2}$ : "Moral maturity has a significant and negative effect on 'benefiting from actions perceived as harmless' dimension of unethical consumer behavior." was accepted. 


\section{Conclusion and Recommendations}

Since it is an indispensable part of companies/brands and is directly related to consumers, a lot of research has been done on the marketing function in the literature, and therefore marketing decisions and activities (product design, advertising, pricing, market research, etc.) have often been the subject of ethical discussions. Interest in ethics in the field of business has increased significantly over the last two decades and has become a topic on which scientists and especially marketing managers concentrate their studies. Although there are extensive studies in the literature on ethics, it is seen that most of these studies focus on the understanding of ethics of sellers. However, consumers are also an important element of the marketing process, and a research without them causes the issues of marketing ethics to fall short and the concept of ethics to be poorly understood.

Consumers must, on the one hand, protect themselves from the unethical behavior of companies; on the other hand, they must act within the framework of relevant social and moral responsibility during their own purchasing behavior. This situation has led to the emergence of the concept of consumer ethics as well as marketing ethics. Consumer ethics is defined as the moral principles and rules that guide individual or group behavior in fulfilling their responsibilities related to the consumption of products and services and the disposal of product residues.It is seen that there are many consumer behavior styles that reveal ethical problems related to consumer behavior in our daily life. Taking a product out of the store without payment, telling the cashier a low price, and changing the price tag of the product represent just a few of the unethical consumer behaviors encountered. It is thought that consumers do not act ethically because they do not encounter any obstacles or see unethical actions as immoral (Babakuş et al., 2004). In this direction, it is thought that the unethical behaviors of the consumers may be affected by some moral factors.

In this context, this study was carried out to investigate the effect of moral maturity on consumers' unethical behavior. The research was conducted by applying the online survey method to 457 consumers residing in Turkey, which was determined by convenience sampling method. After descriptive statistics on the demographic characteristics of the participants were included in the study, first of all, explanatory factor analysis was applied to the statements in the questionnaire in order to determine the factors that affect the participants' evaluation of their moral maturitys and the statements about consumer ethics. After the reliability analysis of the obtained factors, confirmatory factor analysis was applied to test whether the model was compatible with the data. When the goodness of fit values and acceptable values obtained as a result of the analysis were examined, it was concluded that the data was compatible with the model. After confirmatory factor analysis, the hypotheses were tested using Structural Equation Modeling. According to the values obtained as a result of the analysis, it was concluded that moral maturity has a significant effect on consumer ethics dimensions $(p=, 000<.05, p=, 01<.05)$. In the light of the information obtained, H1: "Moral maturity has a significant and negative effect on 'actively benefiting from an illegal situation' dimension of unethical consumer behavior." and $\mathrm{H}_{2}$ : "Moral maturity has a significant and negative effect on "benefiting from actions perceived as harmless' dimension of unethical consumer behavior." hypotheses were accepted. The results obtained in the study are similar to some studies examining morality and consumer ethics in the literature (Kavak et al. 2009; Chowdhury and Fernando, 2014; Vitell et al., 2016; Rodriguez-Rad and Hidalgo, 2018). Chowdhury and Fernando (2014) emphasized in their studies that moral identity has a significant and negative effect on consumers' unethical beliefs.

Muncy and Vitell (1992: 297-298) use the concept of ethics as "moral principles and rules guiding behavior". They define consumer ethics as "moral principles and standards that guide the behavior of individuals or groups while purchasing, using and benefiting from products and services". Therefore, people who have reached a high level of moral maturity must have a harmony between this maturity and their behavior. Moral maturity refers to the assimilation of moral principles, the evaluation of moral rules by the conscience, and the realization of actions in this direction. In order to reach the moral maturity, it is not enough to adopt only moral principles as feelings, thoughts and attitudes. These attitudes and judgments should also be reflected in behaviors and become a habit. In the light of all this information, people who have reached the moral maturity are expected to display ethical behaviors in the society in daily life. According to the findings of the research, as the moral maturity of the individual increases, the possibility of exhibiting unethical consumer behavior decreases; as the level of moral maturity decreases, the possibility of unethical consumer behavior increases. The results obtained show how effective the concept of morality on ethical consumer behavior is. 


\section{S. Sargın - L. Leblebici Koçer 13/2 (2021) 1764-1780}

In this direction, activities can be carried out to increase the level of moral maturity of consumers. Trainings can be given to consumers about ethics. Cooperation with universities, industry and municipalities can be developed to organize consumer ethics literacy seminars. Through public spots, consumers can be informed about the consequences of engaging in unethical behavior. If such consciousness can be created especially in children, children with high levels of moral maturity will tend to exhibit less unethical behavior in the future. In this context, trainings can be given in schools to explain unethical consumer behavior, and even courses can be added to curriculum of the primary and high schools.

Companies can also develop different marketing strategies against consumers with low moral maturity. Consumers engage in some unethical behaviors such as changing the product label during shopping, eating and drinking without paying, keeping quiet even though the cashier realizes that he has given too much change, understating his child's age to take advantage of discounts, or showing the product damaged beforehand as damaged due to his own fault. In order to prevent these behaviors, marketing managers can offer snacks to consumers in the markets, keep the prices at reasonable levels and prevent the labels from being changed; can increase security measures; can follow more flexible policies on returns and exchanges. In addition, if the prices of copy computer software are reduced so that everyone can access them, purchasing pirated products can be prevented. For institutions that use licensed software (eg. educational institutions), purchasing these software can be made easier. The number of cash registers in the stores can be increased for consumers who try to get ahead by not waiting in line at the cash registers.

Besides, marketing managers can also develop different marketing strategies for consumers with a high level of moral maturity and thus reward consumers who behave ethically. For example, rewards such as discounts, coupons, gifts, etc. may be offered to consumers who pay the real price of the product even though the cashier says the price is low. The consumer, who states that the product she/he brought for the exchange has been damaged due to his own fault, can be assisted in return and exchange, or a new product/gift can be given as a reward. For consumers who purchase licensed software for a fee and do not use pirated software, the period of using the software may be extended. Marketing managers can prevent unethical consumer behaviors by applying different marketing strategies to consumers with low/high moral maturity level.

The most important limitation of the research is that the convenience sampling method was used due to the limited time and cost. Therefore, care should be taken when generalizing the results of the research. In future research, one of the methods of random sampling can be used. In addition, when studies on consumer ethics in Turkey are examined, it is seen that its relationship with the concept of morality is not adequately addressed. In future studies, moral concepts such as moral indifference, moral identity, moral value, moral alienation, and the sub-dimensions of self, such as ideal self, real self, and social self can be examined in terms of the relationships between the ethical/unethical behaviors of consumers.

\section{References}

Al-Khatib J. A, Vitell, S. J., Scott, J. and Rawwas, M. Y. A. (1997). Consumer ethics: A cross-cultural investigation, European Journal of Marketing, 31(11-12), 750-767.

Al-Khatib J. A., Dobie K. and Vitell, S. J. (1995). Consumer ethics in developing countries: An empirical investigation, Journal of Euromarketing, 4(2), 87-109.

Altunışık, R., Coşkun, R., Bayraktaroğlu, S. and Yıldırım, E. (2005). Sosyal Bilimlerde Araştırma Yöntemleri Spss Uygulamali, Adapazari, Sakarya Kitabevi.

Arli, D. and Pekerti, A. (2016). Who is more ethical? Cross-cultural comparison of consumer ethics between religious and non-religious consumers, Journal of Consumer Behavior, 16(1), 82-98.

Babakuş, E., Cornwell, T. B., Mitchell, V. and Schlegelmilch, B. (2004). Reactions to unethical consumer behavior across six countries, Journal of Consumer Marketing.

Bakırcığlu, R. (2012). Ansiklopedik Eğitim ve Psikoloji Sözlü̆̆̈̈, Ankara, Anı Yayıncılık.

Bayram, N. (2009). Sosyal Bilimlerde Spss ile Veri Analizi, Ezgi Kitabevi.

Bayram, N. (2010). Yapısal Eşitlik Modellemesine Giriş Amos Uygulamaları, Ezgi Kitabevi.

Bentler, M. and Bonett, D. G. (1980). Significance tests and goodness of fit in the analysis of covariance structures, Psychological Bulletin, 88(3), 588. 
Chan, A., Wong, S. and Leung. (1998). Ethical beliefs of Chinese consumers in Hong Kong. Journal of Business Ethics, 17(11), 1163-1170.

Chen, C. F. and Tsai, D. (2007). How destination image and evaluative factors affect behavioral intentions?, Tourism Management, 28(4), 1115-1122.

Chowdhury, R. M. and Fernando, M. (2014). The relationships of empathy, moral identity and cynicism with consumers' ethical beliefs: The mediating role of moral disengagement, Journal of Business Ethics, 124(4), 677-694.

Çağrıcı, M. (1989). Ahlak, TDV İslam Ansiklopedisi, İstanbul, Türkiye Diyanet Vakfı Yayınları, 1-9.

Çekin, A. (2013). Öğretmen adaylarının ahlaki olgunluk düzeyleri, Kastamonu Ĕğitim Dergisi, 21(1), 1035-1048.

Ecer, F. (2006). Tüketici etiğinin oluşumuna etki eden etmenler ve bir uygulama. Mevzuat Dergisi, 9(103), 1-10.

Erciş, A. and Türk, B. (2016). Etik çerçevesinde tüketim, tüketici ve çevre: Ekolojik okuryazarlığın moderatör rolü, Çukurova Üniversitesi İ̈BF Fakültesi Dergisi, 20(2), 1- 24.

Erciş, A., Altay, Ş. and Türk, B. (2017). Tüketici etiğinin yeniden satın alma davranışı üzerindeki etkisinin suçluluk duygusu bağlamında incelenmesi. Atatürk Üniversitesi İktisadi ve İdari Bilimler Dergisi, 31(2), 229-242.

Erffmeyer, R.C., Keillor, B.D. and LeClair, D. T. (1999). An empirical investigation of Japanese consumer ethics. Journal of Business Ethics, 18(1), 35-50.

Ertuhan, H. and Filizöz, B. (2011). İş etiği ve bankacılık sektöründe bir araştırma, Cumhuriyet Üniversitesi İktisadi ve İdari Bilimler Dergisi, 12(2), 139-157.

Ferrell, O.C. and Gresham, L. G. (1985). A contingency framework for understanding ethical decision making in marketing, Journal of Marketing, 49(3), 87-96.

Fornell, C. and Lacker, D. F. (1981). Evaluating structural equation models with unobservable variables and measurement error, Journal of Marketing Research, 18(1), 39-50.

Forsyth, D. R. (1980). A taxonomy of ethical ideologies. Journal of Personality and Social Psychology, 39(1), 175.

Gürbüz, S. and Şahin, F. (2014). Sosyal Bilimlerde Araştırma Yöntemleri, Ankara, Seçkin Yayıncılık.

Habermas, J. (1982). A Reply to My Critics, In Habermas, London, Palgrave, 219-283.

Hair, J. F., Black, W. C., Babin, B. J. and Anderson, R. E. (2010). Multivariate Data Analysis a Global Perspective, Seventh Edition, New Jersey, Pearson Prentice Hall.

Hazer, O. (2012). Tüketicilerin etik inançlarının incelenmesi, I. Uluslararası Aile ve Tüketici Bilimleri Kongresi Bildiri Kitabı.

Hazer, O. and Öztürk, M. S. (2013). Elderly consumers and ethics, European Conference on Social and Behavioral Sciences, 1-22.

Hoyle, R.H. (1995). The Structural Equation Modeling Approach. In R.H. Hoyle (Ed.), Structural Equation Modeling: Concepts, Issues, and Applications, Thousand Oaks, CA, Sage, 1-15.

Hunt, S. D. and Vitell, S. (1986). A general theory of marketing ethics, Journal of Macromarketing, 6(1), 5-16.

Kavak, B. (2001). Makyavelizm ile tüketicinin ahlaki yargıları arasındaki ilişkiye yönelik ampirik bir inceleme, Ev Ekonomisi Dergisi, 7(8), 11-20.

Kavak, B., Gürel, E. and Eryiğit, Özkan, Ö. (2009). Examining the effects of moral development level, selfconcept, and self-monitoring on consumers' ethical attitudes, Journal of Business Ethics, 88(1), 115-135.

Kılıç, R. (2007). İslâm Kelam Düşüncesinde Ahlâk Anlayışı, R. Kaymakcan ve M. Uyanık (Ed.), Teorik ve Pratik Yönleriyle Ahlâk, İstanbul, Değerler Eğitimi Merkezi, 162-188.

Levin, A., Dato-On, M. C. and Rhee, K. (2004). Money for nothing and hits for free: The ethics of downloading music from peer-to-peer web sites, Journal of Marketing Theory and Practice, 12(1), 48-60.

Lu, L. C. and Lu, C. J. (2010). Moral philosophy, materialism, and consumer ethics: An exploratory study in Indonesia, Journal of Business Ethics, 94(2), 193-210.

Masuda, A., Ishii, H. and Onzo, N. (2019). Effects on consumer attitudes of appeal information of ethical products, A Study on Socio-cultural Influences of Inclusive Business, 189, 1-33. 
Muncy, J. A. and Vitell, S. J. (1992). Consumer ethics: An investigation of the ethical beliefs of the final consumer, Journal of Business Research, 24(4), 297-311.

Nakip, M. (2003). Pazarlama Araştırmaları Teknikler ve (Spss Destekli) Uygulamalar, Ankara, Seçkin Yayıncılık.

Nunnally, J. C. (1978). An overview of psychological measurement, Clinical Diagnosis of Mental Disorders, 97146.

Oyman, M. (2004). Tüketici etiği: Ülkelerarası karşılaştırmalara ve demografik faktörlere dayalı bir araştırma, Eskişehir Osmangazi Üniversitesi Sosyal Bilimler Dergisi, 5(2), 77- 90.

Özden, A. T. (2019). Etik tüketici davranışı: Marka odaklı karar verme tarzı ve demografik değişkenlere göre incelenmesi üzerine bir araştırma, Anadolu Üniversitesi Sosyal Bilimler Dergisi, 19(3), 215-238.

Rawwas, M. Y. (2001). Culture, personality and morality, International Marketing Review 18(2), 188-209.

Rawwas, M. Y. A., Patzer, G. L. and Klassen, M. L. (1995). Consumer ethics in cross-cultural settings entrepreneurial implication, European Journal of Marketing, 29(7), $62-78$.

Raykov, T. and Marcoulides, G. A. (2006). A First Course in Structural Equation Modeling. Mahwah, NJ, Lawrence Erlbaum.

Rest, J. R. (1979). Development in Judging Moral Issues. Minneapolis, MN, Univer.

Rodriguez-Rad, C. J. and Ramos-Hidalgo, E. (2018). Spirituality, consumer ethics and sustainability: The mediating role of moral identity, Journal of Consumer Marketing.

Saray, M. T. and Hazer, O. (2017). Etik tüketici ölçeğinin türkçe uyarlaması; geçerlilik ve güvenilirliğine ilişkin bir çalışma: Hacettepe üniversitesi örneklemi, International Journal of Education Technology and Scientific Researches, 2(4), 258-283.

Schumacker, R. E. and Lomax, R. G. (2004). A Beginner's Guide to Structural Equation Modeling, Mahwah, New Jersey, Lawrence Erlbaum Associates, Inc.

Senemoğlu, N. (2011). Gelişim Öğrenme ve Öğretim, Ankara, Pegem Akademi.

Summers, D. (Ed.). (1995). Longman Dictionary of Contemporary English, Harlow, Longman.

Swaidan, Z., Vitell, S. and Rawwas, M. Y. A. (2003). Consumer ethics: Determinants of ethical beliefs of African Americans, Journal of Business Ethics, 46(2), 175-186.

Şengün, M. (2008). Lise öğrencilerinin ahlaki olgunluk düzeylerinin bazı kişisel değişkenlerine göre incelenmesi (Yüksek Lisans Tezi), On Dokuz Mayıs Üniversitesi, Sosyal Bilimler Enstitüsü, Samsun.

Şengün, M. and Kaya, M. (2007). Ahlaki olgunluk ölçeği: Geçerlik ve güvenirlik çalışması, On Dokuz Mayıs Üniversitesi İlahiyat Fakültesi Dergisi, 24(24-25), 51-64.

Torlak, Ö. (2009), Pazarlama Ahlakı, 5. Baskı, İstanbul, Beta Yayınevi.

Torlak, Ö. and Tiltay, M. A. (2009). Materyalist eğilim, dini değerler ve tüketici ahlakı arasındaki ilişkiler, 14. Ulusal Pazarlama Kongresi, 61-77.

Varinli, İ. (2000). Tüketici etiği ve üniversite öğrencilerine yönelik bir araştırma, Atatürk Üniversitesi İktisadi ve İdari Bilimler Dergisi, 14(1), 297-309.

Vitell, S. J., King, R. A., Howie, K., Toti, J. F., Albert, L., Hidalgo, E. R. and Yacout, O. (2016). Spirituality, moral identity and consumer ethics: A multi-cultural study, Journal of Business Ethics, 139(1), 147-160.

Wilkes, K. V. (1978). The good man and the good for man in Aristotle's ethics, Mind, 87(348), 553-571.

Yazıcıoğlu, Y. and Erdoğan, S. (2004). SPSS Uygulamalı Bilimsel Araştırma Yöntemleri, Ankara, Detay Yayıncılık.

Yurtsever, G. (1998). The ethical beliefs of Turkish consumers, Dokuz Eylül Üniversitesi İktisadi ve İdari Bilimler Fakültesi Dergisi, 13(2), 135-146. 